\title{
Density and Dimensional Stability of a Wood-polymer Nano-Composite from Fast-growing Wood
}

\author{
Istie Rahayu, ${ }^{\mathrm{a}, *}$ Esti Prihatini, ${ }^{\mathrm{a}}$ Akhiruddin Maddu, ${ }^{\mathrm{b}}$ Mersi Kurniati, ${ }^{\mathrm{b}}$ and \\ Wayan Darmawan ${ }^{\mathrm{a}}$
}

\begin{abstract}
The characteristics of ganitri wood can be improved via wood impregnation. The objective of this research was to analyze the density and dimensional stability of a wood polymer nano-composite, i.e., impregnated ganitri wood with a mixture of melamine formaldehyde furfuryl alcohol and nano-SiO 2 . The results showed that the impregnation process improved the physical properties of the impregnated ganitri wood. Impregnation with $0.5 \%$ melamineformaldehyde furfuryl alcohol (MFFA)-nano $\mathrm{SiO}_{2}$ had a significant effect on the density, weight percent gain, anti-swelling efficiency, bulking effect (BE), and water uptake (WU). Increased percentage of density and BE values after being treated by MFFA with $0.5 \%$ nano- $\mathrm{SiO}_{2}$ were $51.2 \%$ and $311.7 \%$, respectively. The percentage decrease in WU was $47.5 \%$ (MFFA with $0.5 \%$ nano-SiO 2 ). Xray diffraction analysis verified a decrease in the crystallinity of the wood cellulose. The melamine formaldehyde furfuryl alcohol and nano- $\mathrm{SiO}_{2}$ polymers were found to cover the wood cell walls and lumens (based on scanning electron microscopy images). The formaldehyde emissions of the wood polymer nano-composite decreased. Therefore, it is possible to produce more environmentally friendly materials through wood polymer nanocomposites.
\end{abstract}

DOI: 10.15376/biores.17.1.750-762

Keywords: Impregnation; Fast-growing species; Nano-SiO 2 ; MFFA; Physical properties

Contact information: a: Department of Forest Products, Faculty of Forestry and Environment, IPB University, Bogor 16680 Indonesia; $b$ : Department of Physics, Faculty of Mathematics and Natural Sciences, Bogor 16680 Indonesia; *Corresponding author: istiesr@apps.ipb.ac.id

\section{INTRODUCTION}

Community forests are widely planted with fast-growing trees. The advantages of fast-growing trees include having a short cutting cycle and large-diameter timber. Elaeocarpus sphaericus Schum. (ganitri/rudraksha wood) is classified as a fast-growing tree species with a large diameter (Rahman 2012). The ganitri tree can be used as a seed/fruit producer (jewelry product), carpentry wood, or as a road protection tree (urban forest). Ganitri trees grow in Manila, Philippines, through Myanmar, and throughout northeastern India, Bangladesh, Nepal, and Bhutan. The ganitri tree is rather light and soft (Siarudin and Widiyanto 2013). This wood can be used for building materials and is classified as durability class IV (Heyne 1987). For example, ganitri wood aged 6 years from Sukabumi, Indonesia has an air-dry specific gravity of 0.35 , and it is included in the durability class IV (Prihatini et al. 2020). However, according to Laksono (2019), ganitri wood aged 6 years has $100 \%$ juvenile wood. Due to the large portion of juvenile wood, wood modification is an effort to improve its quality.

The most commonly used modification technique for wood is impregnation with 
furfuryl alcohol (FA). Furfurylation has been successful in increasing the dimensional stability of wood (Lande et al. 2004; Esteves et al. 2011). Nanotechnology-based treatments in wood modification have been used to improve the quality of fast-growing woods. The results of a study by Hazarika and Maji (2014), who added nano- $\mathrm{SiO}_{2}$ to melamine formaldehyde-furfuryl alcohol (MFFA), showed that nano- $\mathrm{SiO}_{2}$ can also reduce water absorption and improve mechanical properties, fire resistance, and thermal stability of Ficus hispida wood. Nano-SiO 2 was treated with FA, which resulted in the increased hardness, water uptake, and anti-swelling efficiency of poplar wood (Dong et al. 2014). Based on the research of Rahayu et al. (2020), nano silica can effectively improve the dimensional stability and density of sengon wood. Melamine formaldehyde modified with furfuryl alcohol was also able to improve the dimensional stabilization and mechanical properties of Chinese spruce wood. Melamine formaldehyde (MF) resin has been widely used in wood modification because it can react easily in acidic, alkaline, or neutral media (Yao et al. 2017). The formaldehyde content was also a consideration in this study. Formaldehyde emissions from wood products are very important because they have a negative impact on human health. According to Candan and Akbulut (2013), the addition of nano silica materials drastically affects the emission properties of formaldehyde from particleboard and plywood panels.

Therefore, the objective of this research was to analyze the density and dimensional stability of wood polymer nanocomposites originated from impregnated ganitri wood with a mixture of melamine formaldehyde furfuryl alcohol and nano- $\mathrm{SiO}_{2}$.

\section{EXPERIMENTAL}

\section{Materials and Tools}

The ganitri wood samples came from community forests in Sukabumi, West Java, Indonesia. The ganitri tree used was 6 years old and defect-free, with a tree height of 15 meters and a diameter of $36 \mathrm{~cm}$. The chemicals used were melamine, formaldehyde, furfuryl alcohol, $\mathrm{NaOH}$, nano- $\mathrm{SiO}_{2}$ (particle diameter $15 \mathrm{~nm} \pm 5 \mathrm{~nm}$ ), maleic anhydride, universal $\mathrm{pH}$ paper, and demineralized water.

The tools used were an analytical balance, caliper, oven, fan, sonicator, impregnation device, moisture meter, aluminum foil, Oswald viscometer, pycnometer, thermometer, Fourier-transform infrared (FTIR) spectrometer, scanning electron microscope (SEM), X-ray diffractometer (XRD), desiccator, and spectrophotometer.

\section{Preparation of the Test Samples}

The ganitri wood was sawed without distinguishing between the heartwood and sapwood. The test sample size used was $2 \mathrm{~cm}$ x $2 \mathrm{~cm}$ x $2 \mathrm{~cm}$ for the density, weight percent gain (WPG), bulking effect, water uptake (WU), and anti-swelling efficiency (ASE) analyses. Each sample had 5 replications.

\section{Preparation of the Impregnant Solution}

Preparation of the melamine formaldehyde-furfuryl alcohol (MFFA) copolymers

The method utilized referred to Hazarika and Maji (2014), Yao et al. (2017), and Prihatini et al. (2020) for the procedure. Melamine, formaldehyde, and furfuryl alcohol (at a 1 to 3 to 5 mole ratio) were placed in a flask. The pre-reaction started when the $\mathrm{pH}$ of the medium was adjusted via adding a $10 \% \mathrm{NaOH}$ solution until the $\mathrm{pH}$ was between 9.4 and 
9.6, and the temperature was slowly raised to $98^{\circ} \mathrm{C}$. When the solution was clear, furfuryl alcohol was added. After the reaction had run for approximately $10 \mathrm{~min}, 1.5 \%$ maleic anhydrous catalyst was added, and the reaction was continued for approximately $10 \mathrm{~min}$. For impregnation, this MFFA copolymer was prepared at a concentration of $50 \%$.

\section{Dispersion of the nano-SiO 2 in the melamine formaldehyde-furfuryl alcohol (MFFA) copolymers}

This method referred to Hazarika and Maji (2014) for the procedure. Nano $\mathrm{SiO}_{2}$ was immersed in FA-water (at a 1 to $1 \mathrm{~mol}$ ratio) solution for $24 \mathrm{~h}$ with mechanical stirring, then sonicated for $30 \mathrm{~min}$. After that, the MFFA copolymer was slowly added to the nano $\mathrm{SiO}_{2}$ dispersion while being stirred. Afterward, the MFFA copolymer was slowly added to the nano- $\mathrm{SiO}_{2}$ dispersion with stirring. Furthermore, this mixture was sonicated for $15 \mathrm{~min}$. This mixture was made with three nano- $\mathrm{SiO}_{2}$ compositions $(0.5 \%, 1 \%$, and $1.5 \%)$; this was done to find the optimal composition for wood impregnation. After that, the copolymer quality was tested.

\section{Viscosity of copolymer solutions}

The evaluation was performed by Ostwald viscometer (SNI 06-4567 (1998)). Some copolymer solution was put inside the Ostwald viscometer. Then, the time duration was measured for the surface of the copolymer solution to reach from the upper to the lower limit. Viscosity measurements were performed on three duplicates and on demineralized water of $27^{\circ} \mathrm{C}$. The following equation was used for viscosity,

$$
\eta_{s}=\frac{\eta_{0} \cdot t_{s} \cdot \rho_{s}}{t_{0} \cdot \rho_{0}}
$$

where $\eta$ is the viscosity (poise), $\eta_{0}$ is the water viscosity (cP), and $\eta_{s}$ is the copolymer viscosity (cP). The parameter $\rho_{0}$ is water density $\left(\mathrm{g} / \mathrm{cm}^{3}\right)$, to is water flow time (seconds), and $t_{s}$ is copolymer flow time (seconds).

\section{Preparation of the Wood Polymer Nano-Composite (WPnC)}

A furfurylation process was carried out. The furfurylation process consists of three steps, i.e., impregnation, polymerization, and drying. Impregnation was carried out by adapting the method outlined in Hazarika and Maji (2014). In this study, the ganitri wood samples that were previously oven dried were measured and weighed. The wood samples were either untreated or treated. These were put into different containers, followed by the impregnant solution being poured out and put in an impregnation tube. Impregnation was performed via a vacuum treatment of 0.5 bar for $1 \mathrm{~h}$, followed by a pressure of 2 bar for 2 $\mathrm{h}$. The polymerization process was carried out by cleaning the wood samples of the impregnant residue that was still attached to the outside; the samples were then wrapped in aluminum foil and placed in an oven at $90{ }^{\circ} \mathrm{C}$ for $24 \mathrm{~h}$. For the drying process, after the aluminum foil was opened, the samples were reheated at a temperature of $103{ }^{\circ} \mathrm{C} \pm 2{ }^{\circ} \mathrm{C}$ for $24 \mathrm{~h}$. The samples that were oven dried had their dimensions measured and were weighted to determine the density, WPG, BE, WU, and ASE.

\section{Characterization of the Impregnated Ganitri Wood}

Determination of the presence of a mixture of MFFA and nano- $\mathrm{SiO}_{2}$ particles in ganitri wood was carried out using FTIR, XRD, SEM, and energy-dispersive X-ray spectroscopy (EDX). 


\section{Formaldehyde Emission Testing}

For this formaldehyde emission test, a slightly modified version of the method outlined in JIS A standard 1460 (2001) was employed. The wood was cut into several pieces with a total area of $1800 \mathrm{~cm}^{2}$, with as many as 2 sets. Before being tested, preconditioning was carried out at a temperature of $20{ }^{\circ} \mathrm{C} \pm 2{ }^{\circ} \mathrm{C}$ with an air humidity of $65 \%$ $\pm 5 \%$ to reach a constant weight for each sample that was a minimum length of $25 \mathrm{~mm}$. After that, the conditioning test was carried out at a temperature of $20{ }^{\circ} \mathrm{C} \pm 0.5^{\circ} \mathrm{C}$ for $24 \mathrm{~h}$ $\pm 5 \mathrm{~min}$, where the sample was put in a desiccator with $300 \mathrm{~mL}$ of distilled water. The formaldehyde concentrations in the distilled water were determined using a spectrophotometer.

\section{RESULTS AND DISCUSSION}

\section{Copolymer Manufacturing}

The quality of the copolymer test results can be seen in Table 1, i.e., the density, viscosity, solids content, and curing time. The results of the research by Yao et al. (2017) showed that a viscosity value of $13 \mathrm{cP}$ was still easily absorbed into wood. The drying time should be in the range of 4 to $8 \mathrm{~h}$ for easy and fast manufacturing. From the quality test results (Table 1), it was found that both the MFFA copolymers without nano- $\mathrm{SiO}_{2}$ and with nano- $\mathrm{SiO}_{2}$ had the same curing time $(6 \mathrm{~h})$, except for the MFFA copolymers with a $1.5 \%$ nano- $\mathrm{SiO}_{2}$, which took $7 \mathrm{~h}$. The copolymer density increased with the addition of nano$\mathrm{SiO}_{2}$ and increased as the nano- $\mathrm{SiO}_{2}$ concentration increased. The viscosity also increased as the nano- $\mathrm{SiO}_{2}$ concentration increased. The viscosity of the liquid experienced a significant increase in the MFFA copolymer with $1.5 \%$ nano- $\mathrm{SiO}_{2}$ added. From the visual appearance of the MFFA copolymer with $1.5 \%$ nano- $\mathrm{SiO}_{2}$, gelation began to occur after sonication.

Table 1. Copolymer Quality Test Results

\begin{tabular}{|c|c|c|c|c|}
\hline Impregnant Solutions & $\begin{array}{l}\text { Density } \\
\left(\mathrm{g} / \mathrm{cm}^{3}\right)\end{array}$ & $\begin{array}{l}\text { Viscosity } \\
\text { (cP) }\end{array}$ & $\begin{array}{l}\text { Solid Content } \\
(\%)\end{array}$ & $\begin{array}{l}\text { Curing Time } \\
\text { (h) }\end{array}$ \\
\hline MFFA & $1.15 \pm 0.02$ & $3.70 \pm 0.15$ & $19.79 \pm 0.13$ & 6 \\
\hline MFFA with $0.5 \%$ nano- $\mathrm{SiO}_{2}$ & $1.16 \pm 0.02$ & $7.31 \pm 0.03$ & $21.68 \pm 0.04$ & 6 \\
\hline MFFA with $1 \%$ nano-SiO 2 & $1.17 \pm 0.03$ & $8.34 \pm 0.02$ & $22.70 \pm 0.84$ & 6 \\
\hline MFFA with $1.5 \%$ nano- $\mathrm{SiO}_{2}$ & $1.20 \pm 0.02$ & $63.85 \pm 3.32$ & $39.98 \pm 1.25$ & 7 \\
\hline
\end{tabular}

\section{Effect of the Melamine Formaldehyde-Furfuryl Alcohol (MFFA) $\mathrm{Nano}^{-\mathrm{SiO}_{2}}$ Impregnation Treatment on Density and Dimensional Stability of Ganitri Wood}

Impregnation using MFFA copolymers succeeded in increasing the parameters of its physical properties, which included its density, weight percent gain (WPG), bulking effect (BE), water uptake (WU), and anti-swelling efficiency (ASE) (Table 2). Hazarika and Maji (2014) stated that when wood is filled with MFFA, the polymer will fill the lumens and empty cell walls, which results in an increase in density, WPG, ASE, and BE, and a decrease in WU. 


\section{Density and WPG of ganitri wood}

Ganitri wood density values of MFFA and MFFA nano-SiO 2 treated (Table 2) tended to increase compared to untreated ganitri wood. Density values of ganitri wood were $0.41 \mathrm{~g} / \mathrm{cm}^{3}$ (untreated), $0.53 \mathrm{~g} / \mathrm{cm}^{3}$ (MFFA), $0.62 \mathrm{~g} / \mathrm{cm}^{3}$ (MFFA with $0.5 \%$ nano-SiO 2 ), $0.61 \mathrm{~g} / \mathrm{cm}^{3}$ (MFFA with $1 \%$ nano-SiO 2$)$, and $0.60 \mathrm{~g} / \mathrm{cm}^{3}$ (MFFA with $1.5 \%$ nano- $\mathrm{SiO}_{2}$ ). This is in line with the research by Yao et al. (2017), who showed that impregnation with melamine formaldehyde modified with furfuryl alcohol succeeded in increasing the density and WPG. The density of the ganitri wood increased, which was in line with the WPG increasing (Table 2). WPG values of ganitri wood were $45.4 \%$ (MFFA), $65.7 \%$ (MFFA with $0.5 \%$ nano- $\mathrm{SiO}_{2}$ ), $64.2 \%$ (MFFA with $1 \%$ nano- $\mathrm{SiO}_{2}$ ), and $59.3 \%$ (MFFA with $1.5 \%$ nano- $\mathrm{SiO}_{2}$ ). The higher the WPG value, the higher the ganitri wood density. Increased percentage of density values after being treated by MFFA dan MFFA with $0.5 \%$ nano-SiO 2 were $29.3 \%$ and $51.2 \%$, respectively.

\section{Dimensional stability of ganitri wood}

An increase in the WPG value was also directly proportional to the BE value (Table 2). The addition of nano-SiO 2 in the MFFA was also shown to be able to increase the parameters of its physical properties (when compared to the wood without the addition of nano-SiO 2 ). According to Hazarika and Maji (2014), nano-SiO 2 will fill the empty space of wood, thereby reducing its water absorption capacity. In ganitri wood with the addition of $0.5 \%$ nano- $\mathrm{SiO}_{2}$, there was an increase in its physical properties; however, an increase in the nano- $\mathrm{SiO}_{2}$ concentration was not directly proportional to an increase in the physical properties.

The increase in the WPG, BE, density, and ASE values were inversely proportional to the WU. This is presumably because the impregnant layer will reduce the ability of the wood to absorb water. The MFFA copolymer and the addition of nano- $\mathrm{SiO}_{2}$ successfully coated the surface of the cell so that the ability of the wood to absorb water was considerably reduced, which could cause less expansion of the wood. The addition of nano$\mathrm{SiO}_{2}$ is also able to reduce the wood's ability to absorb water; however, an increased concentration of nano- $\mathrm{SiO}_{2}$ was not directly proportional to the decrease in the ability of the wood to absorb water, although it was still lower compared to wood that was impregnated by only MFFA. Generally, increased percentage of BE values after being treated by MFFA dan MFFA with $0.5 \%$ nano- $\mathrm{SiO}_{2}$ were $231.9 \%$ and $311.7 \%$, respectively. Meanwhile the decreased percentages for WU were $21.1 \%$ (MFFA) and $47.5 \%$ (MFFA with $0.5 \%$ nano- $\mathrm{SiO}_{2}$ ).

\section{MFFA copolymer concentration}

In the current study, the physical values increased with nano- $\mathrm{SiO}_{2}$ at a concentration of $0.5 \%$, but all values, including the ASE, decreased at concentrations of $1 \%$ and $1.5 \%$. Although the physical parameters were still higher at $1.0 \%$ and $1.5 \%$ nano- $\mathrm{SiO}_{2}$, they were not significantly different from wood impregnated with MFFA. This was different from the research results of Prihatini et al. (2020), who conducted research on jabon wood and found that there was an increase in the physical properties parameters as the nano- $\mathrm{SiO}_{2}$ concentration increased from $0.5 \%$ to $1 \%$.

This difference is probably due to the size of the ganitri cells, which are smaller than in jabon wood, making it more difficult for fluids to enter the cells. According to Martawijaya et al. (2005), the pore diameter of jabon wood is 130 to $220 \mu \mathrm{m}$, and the number of pores is 2 to 5 per $\mathrm{mm}^{2}$, while Ganitri has a pore diameter of 84.1 to $117.9 \mu \mathrm{m}$ 
with a pore number of 5 to 7 per $\mathrm{mm}^{2}$ (Prihatini et al. 2020). This was in accordance with $\mathrm{Xu}$ (2020), who stated that wood impregnation is essentially the process of removing water or air in macropores and replacing it with resin, so the cell size will have an effect.

However, at the same $1.5 \%$ nano- $\mathrm{SiO}_{2}$ concentration, the physical properties still decreased. The decrease in the value of the physical properties of the mixture was probably due to the change in the form of the copolymer mixture into a gel, which could not as easily penetrate the wood cells. Based on the results of the quality test, the increase in viscosity was also high. This high viscosity was thought to cause reduced liquid absorption by the wood, corresponded to the results of the study by Gavrilovic-Grmusa et al. (2012), who stated that the increase in the viscosity of UF resin caused a decrease in the absorption of adhesive by wood. Xu (2020) stated that large molecules have a high viscosity, which also inhibits resin penetration. According to Milea et al. (2011), with changes in the $\mathrm{pH}$ and a close distance between particles due to solvent evaporation, the surface charge will decrease, and gelation will take place.

Table 2. Ganitri Wood Dimensional Stability Testing

\begin{tabular}{|c|c|c|c|c|c|}
\hline Treatments & $\begin{array}{c}\text { WPG } \\
(\%)\end{array}$ & $\mathrm{BE}(\%)$ & $\begin{array}{c}\text { Density } \\
\left(\mathrm{g} / \mathrm{cm}^{3}\right)\end{array}$ & WU (\%) & ASE (\%) \\
\hline Untreated Ganitri & - & $\begin{array}{c}1.88 \\
( \pm 1.01)\end{array}$ & $\begin{array}{c}0.41 \\
( \pm 0.02)\end{array}$ & $\begin{array}{c}86.34 \\
( \pm 5.30)\end{array}$ & - \\
\hline Ganitri MFFA & $\begin{array}{c}45.42^{\mathrm{a}} \\
( \pm 2.78)\end{array}$ & $\begin{array}{c}6.24^{\mathrm{a}} \\
( \pm 0.88)\end{array}$ & $\begin{array}{c}0.53^{\mathrm{a}} \\
( \pm 0.01)\end{array}$ & $\begin{array}{c}68.14^{\mathrm{b}} \\
( \pm 5.11)\end{array}$ & $\begin{array}{c}53.03^{\mathrm{a}} \\
( \pm 6.34)\end{array}$ \\
\hline Ganitri MFFA with 0.5\% nano-SiO 2 & $\begin{array}{c}65.73^{\mathrm{b}} \\
( \pm 4.56)\end{array}$ & $\begin{array}{c}7.74^{\mathrm{b}} \\
( \pm 1.28)\end{array}$ & $\begin{array}{c}0.62^{\mathrm{b}} \\
( \pm 0.03)\end{array}$ & $\begin{array}{c}45.32^{\mathrm{a}} \\
( \pm 4.88)\end{array}$ & $\begin{array}{c}70,19^{\mathrm{b}} \\
( \pm 5.79)\end{array}$ \\
\hline Ganitri MFFA with 1\% nano-SiO 2 & $64.20^{\mathrm{b}}$ & $7.72^{\mathrm{b}}$ & $0.61^{\mathrm{b}}$ & $45.58^{\mathrm{a}}$ & $67.35^{\mathrm{b}}$ \\
& $( \pm 5.26)$ & $( \pm 0.31)$ & $( \pm 0.01)$ & $( \pm 1.49)$ & $( \pm 6.46)$ \\
\hline Ganitri MFFA with 1.5\% nano-SiO 2 & $59.30^{\mathrm{b}}$ & $7.38^{\mathrm{ab}}$ & $0.60^{\mathrm{b}}$ & $48.71^{\mathrm{a}}$ & $56.58^{\mathrm{a}}$ \\
& $( \pm 3.84)$ & $( \pm 0.72)$ & $( \pm 0.02)$ & $( \pm 6.08)$ & $( \pm 5.89)$ \\
\hline
\end{tabular}

Note: *The value in parentheses () indicates the standard deviation value; ${ }^{\text {a-c }}$ Values followed by the different letters show real difference according to the Duncan test (the value is the average of 5 replications)

The results of the statistical analysis showed that ganitri wood treated with MFFA with the adddition of nano- $\mathrm{SiO}_{2}$ was significantly different from ganitri wood without the nano- $\mathrm{SiO}_{2}$ treatment. Ganitri wood had the highest increase in physical parameters with the addition of $0.5 \%$ nano $\mathrm{SiO}_{2}$.

\section{Fourier-Transform Infrared (FTIR) Analysis}

The FTIR spectrum of nano-SiO 2 is shown in Fig. 1 (graph a). From Fig. 1, it can be seen that the nano-SiO 2 spectrum exhibited 3 peaks, i.e., $800 \mathrm{~cm}^{-1}$, which is a siloxane ( $\mathrm{Si}-\mathrm{O}-\mathrm{Si}$ ) functional group, $1034 \mathrm{~cm}^{-1}$, which is a Si-OC group, and a silanol ( $\left.\mathrm{Si}-\mathrm{OH}\right)$ group at the range of $3063 \mathrm{~cm}^{-1}$ to $3673 \mathrm{~cm}^{-1}$. The presence of this silanol (Si-OH) group agreed with Launer and Arkles (2013), who stated that silanol has an absorption peak at a wave number range of 3200 to $3400 \mathrm{~cm}^{-1}$ and the sharpest peak at wave number $3690 \mathrm{~cm}^{-1}$. The siloxane group ( $\mathrm{Si}-\mathrm{O}-\mathrm{Si}$ ), which has a peak at a wavelength of $810 \mathrm{~cm}^{-1}$, agreed with the research by Raabe et al. (2018). 
The FTIR test results of untreated ganitri wood (as shown in Fig 1. graph b) are characterized by the absorption bands at $3425 \mathrm{~cm}^{-1}$ (-OH stretching), $2916 \mathrm{~cm}^{-1}$ and 2843 $\mathrm{cm}^{-1}$ ( $-\mathrm{CH}_{2}$ asymmetric stretching), $1744 \mathrm{~cm}^{-1}$ (C=O stretching), $1666 \mathrm{~cm}^{-1}$ for $(-\mathrm{OH}$ bending), and $1026 \mathrm{~cm}^{-1}$ (C-O stretching). The presence of nano- $\mathrm{SiO}_{2}$ (as shown in Fig. 1 graph $\mathrm{d}$ through $\mathrm{f}$ ) in the composite caused a decrease in the intensity of the hydroxyl group $(-\mathrm{OH})$ and the carbonyl group. The peak intensity of the $-\mathrm{CH}$ group of the treated wood was lower the $-\mathrm{CH}$ peak intensity of untreated. The intensity of the carbonyl group also decreased due to the formation of hydrogen bonds with the hydroxyl groups on the silica surface (Motaung and Luyt 2010). For the Si-O-Si group, peaks are formed at different wave numbers. In wood, the Si-O-Si group has a peak at the wave number of $1018 \mathrm{~cm}^{-1}$ (asymmetric stretching) (Coates 2006). The shift of the peak to a higher wave number indicates an interaction between the nano- $\mathrm{SiO}_{2}$ and the wood. According to Li et al. (2015), a shift towards larger numbers occurs when the particle size increases. Hydrogen bonding with the siloxane (Si-O-Si) group causes a reduction in the amount of hydroxyl group. The shift in the wave number to a larger direction indicates that hydroxyl groups are being replaced by $\mathrm{Si}-\mathrm{O}-\mathrm{Si}$ groups. This causes a reduction in the ability of wood to absorb water. This corresponds with the findings of Hazarika and Maji (2014), who reported a decrease of hydroxyl group intensity with the increase of nano- $\mathrm{SiO}_{2}$ amount in the composite. The inclusion of the $\mathrm{Si}-\mathrm{O}-\mathrm{Si}$ groups also increased the weight of the wood, so its WPG and density will also increase. From the solid content test results, it was also seen that the addition of nano- $\mathrm{SiO}_{2}$ increased the solids content.

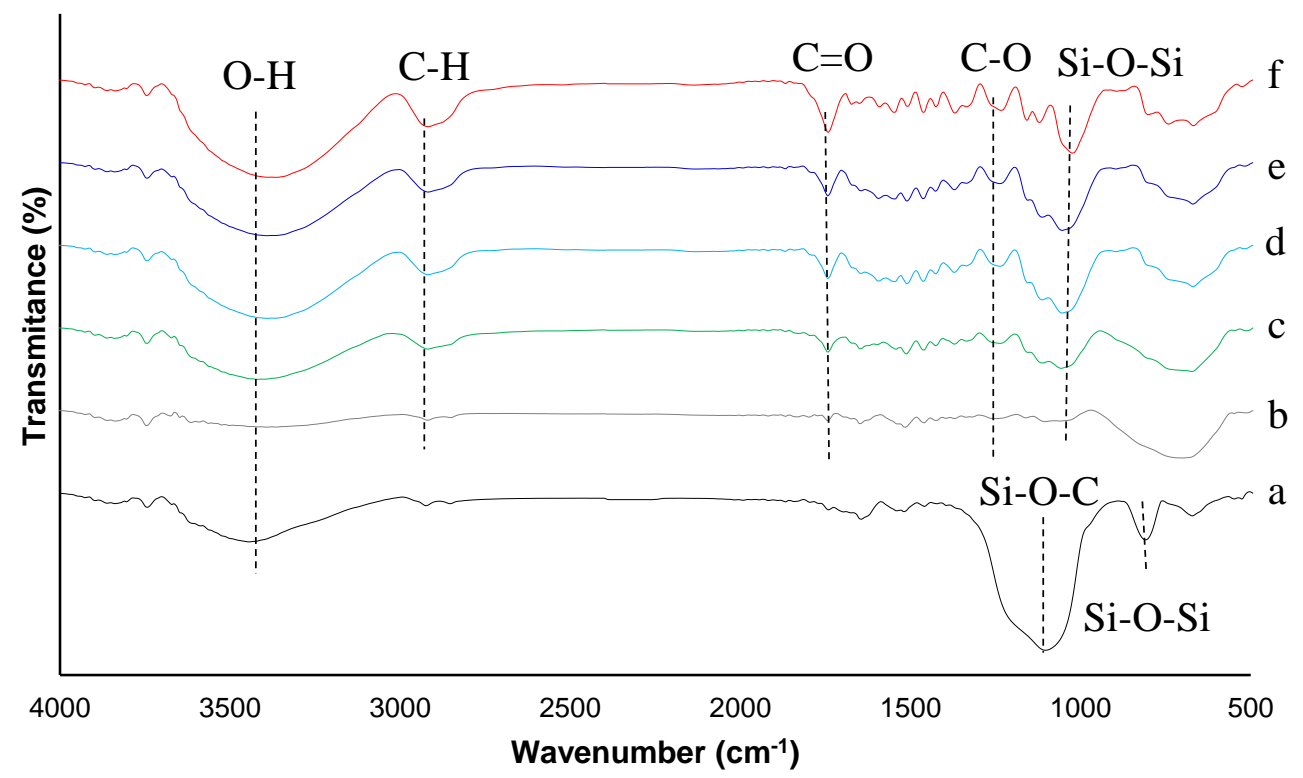

Fig. 1. The ganitri wood FTIR spectrum: (a) nano $\mathrm{SiO}_{2}$; (b) untreated; (c) MFFA; (d) MFFA nano$\mathrm{SiO}_{2}$ 0.5\%; (e) MFFA nano-SiO 2 1\%; and (f) MFFA nano-SiO 2 1.5\%

\section{X-ray Diffraction (XRD) Analysis}

From the XRD curve shown in Fig. 2, the untreated wood had sharper peaks, so its crystallite value was high (as shown in Fig 2. graph a). The untreated wood showed broad diffraction peaks at $2 \theta 22.84^{\circ}$ with 012 cellulose crystalline fields. Two additional small peaks appeared at $2 \theta 16^{\circ}$ and $44.54^{\circ}$, with crystal fields of 020 and 050 , respectively. After MFFA and MFFA nano- $\mathrm{SiO}_{2}$ treatment occurred, the peak intensity decreased (Fig 2. 
graph b through e). For ganitri wood with a $0.5 \%$ MFFA-nano- $\mathrm{SiO}_{2}$ treatment, at an angle of $2 \theta$ by $16^{\circ}$, the graph tends to be flat. This indicates a decrease in the crystallinity of wood cellulose. Figure 2 shows that the nano- $\mathrm{SiO}_{2}$ and MFFA had wide diffraction peaks, which shows that they were both amorphous (Fig. 2 graph $f$ and $g$ ).

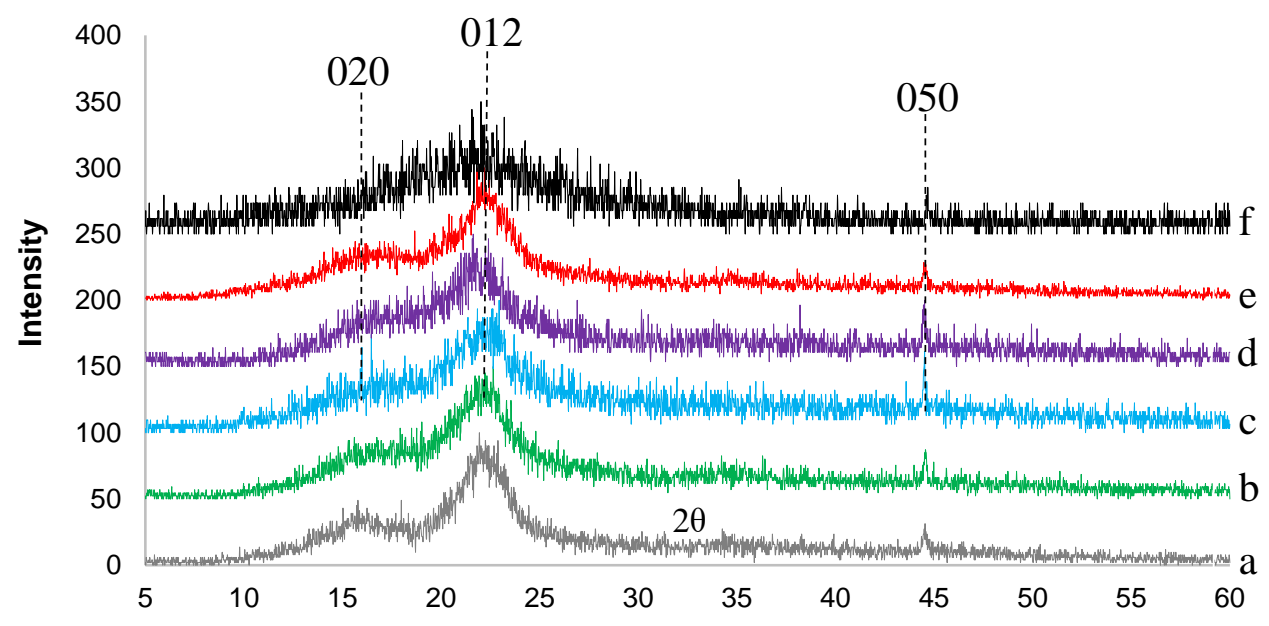

Fig. 2. The ganitri wood XRD results: (a) untreated; (b) MFFA; (c) MFFA nano-SiO $2 ~(0.5 \%)$; (d) MFFA nano-SiO 2 (1\%); (e) MFFA nano-SiO2 2 (1.5\%); and (f) nano-SiO 2

\section{Results of Testing the Degree of Crystallinity}

The degrees of crystallinity associated with the treatments are shown in Table 3. The untreated ganitri wood cellulose showed the highest degree of crystallinity. The lowest degree of crystallinity for both of the two wood samples was the same treatment, i.e., the wood treated with $0.5 \%$ MFFA nano- $\mathrm{SiO}_{2}$. This was in agreement with the results by Hazarika and Maji (2014), who stated that nano silica impregnation with MFFA copolymers can reduce the degree of crystallinity of cellulose. The results of research by Raabe et al. (2018) also stated that coating the fiber surface with nanosilica reduced the degree of crystallinity by $15 \%$. The results of research by Tang et al. (2017) showed that the addition of $\mathrm{SiO}_{2}$ increased the formation of interfacial hydrogen bonds with fibers. The increase in the formation of hydrogen bonds with the Si-O-Si group caused the number of hydroxyl groups to decrease. Shiraishi et al. (1979) reported that chemical grafting reactions occurred in the amorphous regions of wood cellulose. The polymer reacts on the surface of the crystallite to open some of the hydrogen-bound cellulose chains, so that more amorphous cellulose is produced. A decrease in the degree of crystallinity indicates the formation of hydrogen bonds between silica and wood, so that the number of hydroxyl groups will decrease. This was in line with the FTIR results. Decreasing the crystallinity index will increase the physical properties of ganitri wood. In addition, ganitri wood treated with MFFA nano- $\mathrm{SiO}_{2} 1.5 \%$ showed a greater degree of crystallinity than ganitri wood treated with MFFA and MFFA nano- $\mathrm{SiO}_{2}$ (at $0.5 \%$ and $1 \%$ concentrations). This was probably due to the gelation process, which makes the copolymer more difficult to penetrate the wood. It could lead to less cellulose polymer being broken down in order to bond with MFFA copolymer. However, the degree of crystallinity was still smaller when compared to the untreated wood. This corresponded to Hazarika and Maji (2014), who found the same trend in Ficus hispida. 
Table 3. Results of the Wood Crystallinity Index Test

\begin{tabular}{|c|c|}
\hline \multirow{2}{*}{ Treatment } & Degree of Crystanility (\%) \\
\hline & Ganitri wood \\
\hline Untreated Ganitri & 22.57 \\
\hline Ganitri MFFA & 16.83 \\
\hline Ganitri MFFA with $0.5 \%$ nano-SiO 2 & 13.91 \\
\hline Ganitri MFFA with $1 \%$ nano-SiO 2 & 15.51 \\
\hline Ganitri MFFA with $1.5 \%$ nano-SiO 2 & 20.17 \\
\hline Nano silica & 21.17 \\
\hline
\end{tabular}

\section{Scanning Electron Microscopy (SEM) Test Results}

Figure 3 shows the electron micrograph of the untreated and treated ganitri wood samples. It can be seen that wood that was not treated had empty pits and looked hollow, which means that it had empty space and empty cell walls (Fig. 3a and 3b). The impregnation process caused the entry of impregnant material into the wood cells. The presence of polymer deposits on the cell walls and pits can be seen in the wood samples that underwent the MFFA treatment (Fig. 3b) and in the wood treated with MFFA nano$\mathrm{SiO}_{2}$ (Figs. 3c through 3e). After receiving the MFFA treatment, the pits that previously had empty space became evenly closed. Indications of the presence of nano- $\mathrm{SiO}_{2}$ can be detected by several white deposits located on the cell walls and pits between the ganitri wood cells after being impregnated with the MFFA nano-SiO 2 (Figs. 3d through 3e). Nano$\mathrm{SiO}_{2}$ was able to get into the pits, stick to, and even cover almost all the pore walls in the wood. In addition, Fig. 3 shows the amount of silica adhering to the surface of the wood cell, but it did not cover all the surface of the pits. Figure $3 \mathrm{e}$ shows the pits of the ganitri wood cells were still visible.
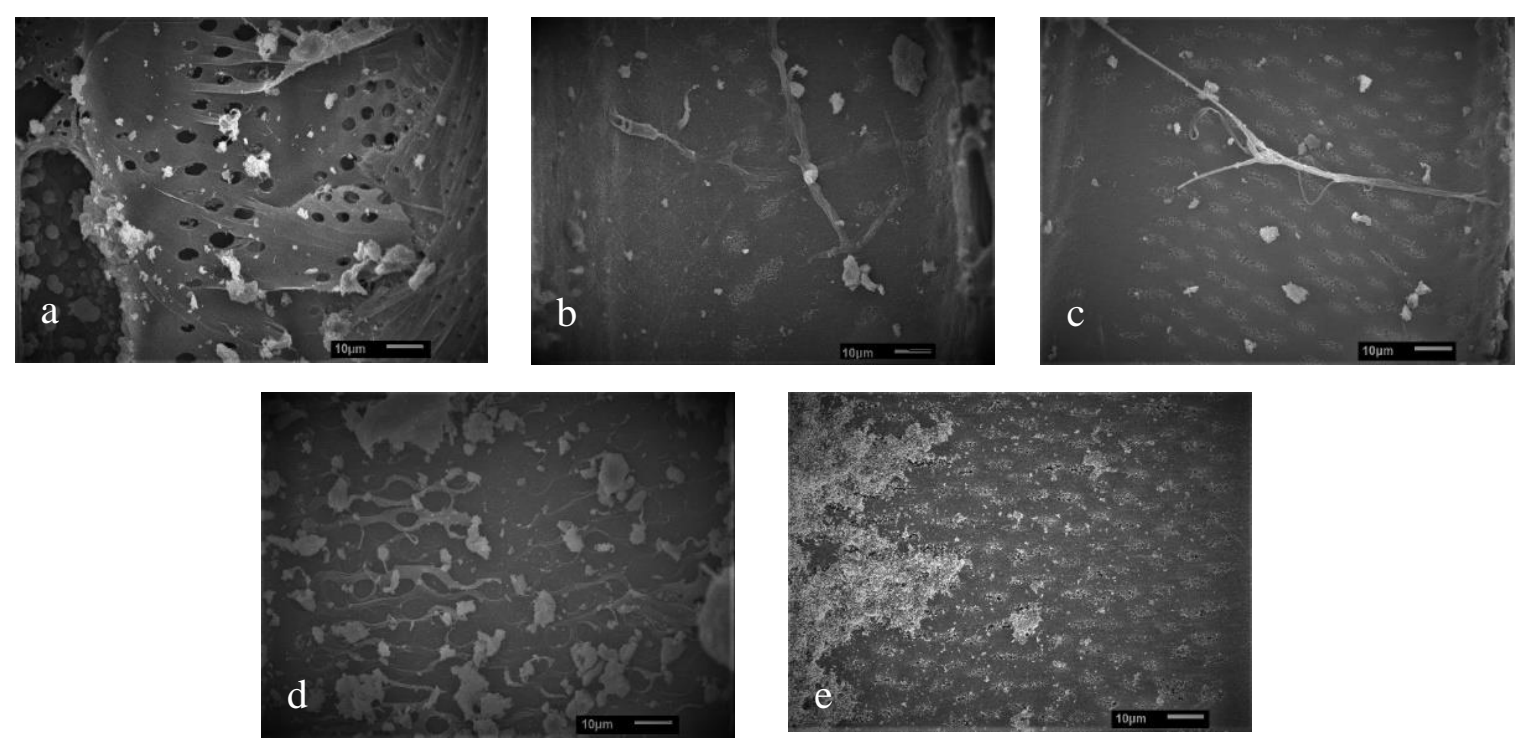

Fig. 3. SEM results of the tangential cross section of ganitri wood (1000x): (a) untreated; (b) MFFA; (c) MFFA nano-SiO 2 0.5\%; (d) MFFA nano-SiO 2 1\%; and (e) MFFA nano- $\mathrm{SiO}_{2} 1.5 \%$ 
The EDX analysis results of the MFFA impregnated ganitri wood with nano $\mathrm{SiO}_{2}$ added showed the presence of silica content. The silica content in the wood impregnated with MFFA nano-SiO 2 increased as the percentage of nano- $\mathrm{SiO}_{2}$ increased.

Table 4. EDX Test Results

\begin{tabular}{|c|c|}
\hline \multirow{2}{*}{ Treatment } & Silica Content (\% mass) \\
\cline { 2 - 2 } & Ganitri wood \\
\hline Ganitri MFFA with $0.5 \%$ nano-SiO & \\
\hline Ganitri MFFA with $1 \%$ nano- $\mathrm{SiO}_{2}$ & 0.23 \\
\hline Ganitri MFFA with $1.5 \%$ nano-SiO & 0.32 \\
\hline
\end{tabular}

\section{Formaldehyde Emission Test}

The results of the formaldehyde emission test for wood impregnated with MFFA and MFFA nanoSiO 2 are shown in Table 5. The test results show that using both MFFA and MFFA with nano silica added resulted in formaldehyde emissions that still met the JIS A standard 1460 (2001), because the formaldehyde levels were below $0.5 \mathrm{mg} / \mathrm{L}$. This means that the wood products produced were safe for the environment.

Table 5. Formaldehyde Emission Levels

\begin{tabular}{|c|c|}
\hline Treatments & Formaldehyde Emission Levels (mg/L) \\
\hline Ganitri MFFA & 0.3144 \\
\hline Ganitri MFFA with 0.5\% nano-SiO 2 & 0.1962 \\
\hline
\end{tabular}

From the table, it can be seen that the formaldehyde emission from wood with the addition of nano $\mathrm{SiO}_{2}$ had lower emission results than the wood without nano $\mathrm{SiO}_{2}$. This was in accordance with Lin et al. (2006), who stated that when the nano- $\mathrm{SiO}_{2}$ content was below $1.5 \%$, the amount of free formaldehyde decreased. Salari et al. (2013) reported that the addition of $\mathrm{SiO}_{2}$ nanoparticles at concentrations between $1 \%$ and $3 \%$ was able to reduce formaldehyde emissions in oriented strand board (OSB) panels. This was reinforced by the results of the research by Candan and Akbulut (2013), who added nano- $\mathrm{SiO}_{2}$ to plywood boards. This reduction in formaldehyde emissions is believed to occur because hydrogen bonding occurs between the nano-SiO 2 and formaldehyde (Lin et al. 2006; Roumeli et al. 2012).

\section{CONCLUSIONS}

Based on the present results, it is concluded that ganitri wood samples can be impregnated with melamine-formaldehyde furfuryl alcohol (MFFA) and nano-SiO 2 copolymers under vacuum and compressed conditions. The conclusions in detail were as follows:

1. Impregnation of wood with MFFA and nano-SiO 2 copolymers can increase the physical properties of ganitri wood, i.e., an increased density, weight percentage gain (WPG), bulking effect (BE), anti-swelling efficiency (ASE), and a decreased water uptake (WU). Increased percentage of density and BE values after being treated by MFFA with $0.5 \%$ nano- $\mathrm{SiO}_{2}$ were $51.2 \%$ and $311.7 \%$, respectively, while the decreased percentage for WU was $47.5 \%$ (MFFA with $0.5 \%$ nano- $\mathrm{SiO}_{2}$ ). The MFFA and nano- 
$\mathrm{SiO}_{2}$ copolymer impregnation was influenced by the wood building cells and the cell size.

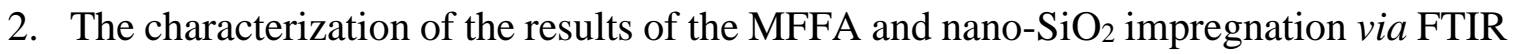
showed a shift in the peak of Si-O-Si toward a higher wave number, which indicated an interaction between the nano- $\mathrm{SiO}_{2}$ and the wood.

3. The results of the X-ray diffraction (XRD) analysis showed that there was a decrease in the crystallinity of wood cellulose after impregnating with MFFA and nano-SiO 2 copolymers.

4. The presence of MFFA and nano-SiO 2 polymers in the wood cell walls and cell lumens was confirmed via scanning electron microscopy (SEM) testing.

5. Based on the test results of the physical properties and the characterization via Fourier transform infrared (FTIR), XRD, and SEM, they showed that the addition of $0.5 \%$ nano- $\mathrm{SiO}_{2}$ in the MFFA copolymer was the optimum concentration for the impregnation of ganitri wood.

6. The results of the formaldehyde emission testing on wood impregnated with MFFAnano- $\mathrm{SiO}_{2}$ at $0.5 \%$ showed that the addition of nano $\mathrm{SiO}_{2}$ was able to reduce the formaldehyde emissions. Impregnated wood produced low formaldehyde emissions and met JIS A standard 1460 (2001), so that it can be considered environmentally friendly.

\section{ACKNOWLEDGMENTS}

The authors are grateful for the support of the Ministry of Education, Culture and Research and Technology of Indonesia (Grant No. 1/E1/KP.PTNBH/2021 and Grant No. 8/E1/KPT/2021).

\section{REFERENCES CITED}

Candan, Z. and Akbulut, T. (2013). "Developing environmentally friendly wood composite panels by nanotechnology," BioResources 8(3), 3590-3598. DOI: 0.15376/biores.8.3.3590-3598

Coates, J. (2006). "Interpretation of infrared spectra, a practical approach," in: Encyclopedia of Analytical Chemistry, Wiley, Hoboken, NJ.

Dong, Y., Yan, Y., Zhang, S., and Li, J. (2014). "Wood/polymer nanocomposites prepared by impregnation with furfuryl alcohol and nano $\mathrm{SiO}_{2}$," BioResources 9(4), 6028-6040. DOI: 10.15376/biores.9.4.6028-6040

Esteves, B., Nunies, L., and Pereira, H. (2011). "Properties of furfurilated wood (Pinus pinaster)," European Journal of Wood Products 69(4), 521-525. DOI: 10.1007/s00107-010-0480-4

Gavrilovic-Grmusa I., Dunky M., Miljkovic J., and Djiporovic-Momcilovic M. (2012). "Influence of the viscosity of UF resins on the radial and tangential penetration into poplar wood and on the shear strength of adhesive joints," Holzforschung 66(7), 849856. DOI: $10.1515 / \mathrm{hf}-2011-0177$

Hazarika, A., and Maji, T. K. (2014). "Properties of softwood polymer composites 
impregnated with nanoparticles and melamine formaldehyde furfuryl alcohol copolymer," Journal of Polymer Engineering and Science 1019-1029. DOI: 10.1002/pen.23643

Heyne, K. (1987). Indonesian Useful Plants, Forestry Research and Development Agency, Jakarta, Indonesia.

JIS A 1460 (2001). "Building boards determination of formaldehyde emission Desiccator method," Japanese Standards Association, Tokyo, Japan.

JIS K 6833 (1980). “General testing method for adhesives,” Japanese Standards Association, Tokyo, Japan.

KLHK (2018). Environmental and Forestry Statistics 2018, Ministry of Environment and Forestry, Jakarta, Indonesia.

Laksono, G. D. (2019). Determination of the Transition Point of Juvenile Wood to Mature Wood on Ganitri Wood, Bogor Agricultural Institute, Bogor, Indonesia.

Lande, S., Westin, M., and Schneider, M. (2004). "Properties of furfurylated wood," Scandinavian Journal of Forest Research 19(5), 22-30. DOI: 10.1080/0282758041001915

Launer, P. J., and Arkles, B. (2013). "Infrared analysis of organosilicon compounds: Spectra-structure correlations," in: Silicon Compounds: Silanes and Silicones, Gelest Inc. Morrisville, PA.

Li, M., Yu, Y., Li, J., Chen, B., Wu, X., Tian, Y., and Chen, P. (2015). "Nanosilica/ carbon composite sphere as anodesin Li-ion batteries with excellent cycle stability," Journal of Materials Chemistry A 3(4), 1476-1482. DOI: 10.1039/C4TA05288A

Lin, Q., Yang, G., Liu, J., and Rao, J. (2006). "Property of nano-SiO 2 /urea formaldehyde resin," Frontiers of Forestry in China 1(2), 230-237, DOI: 10.1007/s11461-0060024-6

Martawijaya, A., Kartasujana, I., Mandang, Y., Prawira, S., and Kadir, K. (2005). Atlas of Indonesian Timber Volume II, Forestry Research and Development Agency, Ministry of Forestry, Java, Indonesia.

Milea, C. A., Bogatu, C., and Duta, A. ( 2011). "The influence of parameters in silica solgel process," Bulletin of the Transilvania University of Braşov Series I: Engineering Science 4(53), 59-66.

Motaung, T., and Luyt, A. (2010). "Effect of maleic anhydride grafting and the presence of oxidized wax on the," Materials Science and Engineering: A 527(3), 761-768. DOI: 10.1016/j.msea.2009.08.065

Prihatini, E., Maddu, A., Rahayu, I. S., and Kurniati, M. (2020). "The nature of ganitri wood (Elaeocarpus sphaericus (Gaertn.) K. Schum.) from Sukabumi and its potential uses," Jurnal Ilmu Kehutanan 14(1), 109-118. DOI: 10.22146/jik.57480

Raabe, J., Santos, L. P. d., Menezzi, C. H. S. D., and Tonoli, G. H. (2018). "Effect of nano-silica deposition on cellulose fibers on the initial hydration of the Portland cement," BioResources 13(2), 3525-3544. DOI: 10.15376/biores.13.2.3525-3544

Rahayu, I. Darmawan, W., Zaini, L. H., and Prihatini, E. (2020). "Characteristic of fast growing wood impregnated with nano particles," Journal of Forestry Research 31, 677-685. DOI: 10.1007/s 11676-019-00902-3

Rahman, E. (2012). "Study of potential utilization of ganitri (Elaeocarpus spp.)," Journal of Plant Partners 7(2), 39-50.

Roumeli, E., Papadopoulou, E., Pavlidou, E., Vourlias, G., Bikiaris, D., Paraskevopoulos, K. M., and Chrissafis, K. (2012). "Synthesis, characterization and analysis of thermalurea-formaldehyde / nanoSiO 2 resin," Thermochimica Acta 527, 33-39. DOI: 
10.1016/j.tca.2011.10.007

Salari, A., Tabarsa, T., Khazaeian, A., and Saraeian, A. (2013). "Improving some of applied properties of oriented strand board (OSB) made from underutilized low quality paulownia (Paulownia fortunie) wood employing nano-SiO,," Industrial Crops and Products 42, 1-9. DOI:10.1016/j.indcrop.2012.05.010

Siarudin, M., and Widiyanto, A. (2013). "Sawmill characteristics of ganitri (Elaeocarpus ganitrus Roxb.) from community forest with agroforestry pattern," Journal of Tropical Forests 1(2), 1-17.

SNI 06-4567-1998 (1998). "Liquid phenol formaldehyde for plywood adhesive," Badan Standardisasi Nasional, Jakarta, Indonesia.

Tang, C., Li, X., Li, Z., and Hao, J. (2017). "Interfacial hydrogen bonds and their influence mechanism on increasing the thermal stability of nano- $\mathrm{SiO}_{2}$-modified metaaramid fibres," Polymers 9(10), 1-18. DOI: 10.3390/polym9100504

$\mathrm{Xu}, \mathrm{W}$. (2020). "Wood modification with resin impregnation technology for value-added services," SVOA Materials Science \& Technology 2(1), 9-21.

Yao, M., Yang, Y., Song, J., Yu, Y., and Jin, Y. (2017). "Melamine formaldehyde modified furfurylation to improve Chinese fir's dimensional stability and mechanical properties," BioResources 12(2), 3057-3066. DOI: 10.15376/biores.12.2.3057-3066

Article submitted: September 13, 2021; Peer review completed: November 6, 2021;

Revised version received: November 21, 2021; Accepted: November 22, 2021;

Published: December 7, 2021.

DOI: 10.15376/biores.17.1.750-762 